\title{
BODY MASS INDEX OF STUDENTS WITH INTELLECTUAL DISABILITIES IN BUCHAREST
}

\author{
Vicol Eduard ȘUȚĂ ${ }^{1 *}$, Tiberiu TĂTARU ${ }^{2}$, Laurenţiu OPREA ${ }^{3}$, Lizia Ioana ȘUȚ $\breve{A}^{1}$ \\ 1 “Constantin Păunescu” Special School, Bucharest, Romania \\ 2 "Constantin Brâncuși” University, Târgu Jiu, Romania \\ ${ }^{3}$ School Inspectorate, Bucharest, Romania \\ *Corresponding author: vicol79@yahoo.com
}

DOI: $10.35189 /$ iphm.icpesk.2019.46

\begin{abstract}
The aim of this research was to compare the Body Mass Index (BMI) of students with mental disabilities enrolled in special educational institutions with the Body Mass Index of students in public educational institutions, with the purpose of adapting/perfecting the learning process for the Physical Education and Sport subject at primary level in special educational institutions. During this project, we decided to verify whether there were significant differences in height, weight or BMI between the two types of students (students enrolled in special educational institutions and students in the public schools of Bucharest). The research sample was composed of 120 students separated into 8 groups of 15 students each: 2 groups of girls enrolled in $5^{\text {th }}$ grade (special education and the corresponding group enrolled in public schools), 2 groups of girls in $8^{\text {th }}$ grade, 2 groups of boys in $5^{\text {th }}$ grade and 2 groups of boys in $8^{\text {th }}$ grade. Therefore, comparisons were made between these two types of students, corresponding to their age and gender. Regarding the statistical methods, the mathematical SPSS program was used by applying the nonparametric Mann-Whitney U Test. The results of the comparisons showed that there were differences in height and weight between the students enrolled in special and public educational institutions. However, in terms of Body Mass Index, there were no significant differences between students.
\end{abstract}

Keywords: special education, middle school, Body Mass Index.

\section{Introduction}

Specialised studies on the motricity of students with intellectual disabilities have been done lately worldwide, the focus being on the level of development of their motor skills (Hartman, Houwen, Scherder, \& Visscher, 2010). Authors such as Frey and Chow (2006), Stewart et al. (2009), or Lloyd, Temple and Foley (2012) addressed the topic of the Body Mass Index (BMI) in children with intellectual disabilities. In the Romanian literature, for example, a comprehensive study by Stănescu et al. (2015) shows the BMI implications on children's health.

In this paper, we carried out a cross-sectional study to compare the anthropometric indices (height and weight) and Body Mass Index of students with intellectual disabilities with the values scored by students enrolled in mainstream schools. To certify the obtained data, the recorded values were shown in percentile graphs.

Purpose of the research

The purpose of this research is to diagnose significant differences in the somatic indexes and Body Mass Index of students with intellectual disabilities and those enrolled in mainstream schools in Bucharest.

Objectives of the research

The objectives of the research are:

1. Establishing the level of knowledge by synthesising general information on the anthropometric indices and Body Mass Index of children with intellectual disabilities;

2. Assessing the anthropometric indices and determining the Body Mass Index of children enrolled in both educational systems: special education and mainstream schools;

3. Summarising the collected data and creating a database;

4. Comparing the values scored by students with disabilities and those attending mainstream schools;

5. Reaching a conclusion for the research.

Hypothesis of the research

The comparison between the BMI of students in the special educational system and mainstream schools should not reveal any significant statistical differences.

Tasks of the research

The tasks resulting from the establishment of the objectives were the following: 
1. Acquiring information about the connection between height and weight by studying the literature;

2. Measuring the height and body mass of 60 students enrolled in the special educational system and 60 students in mainstream schools;

3. Determining the Body Mass Index for the 120 students;

4. Creating a database for the height, body mass and Body Mass Index of students;

5. Determining the statistical mathematical tests through which significant differences between the two types of students would be diagnosed;

6. Data analysis, processing and interpretation;

7. Reaching a final conclusion for the research.

\section{Material and Methods}

\section{Research sample. Experimental groups}

To conduct the research, 120 students were tested, 60 of them being enrolled in 3 special education institutions, and the other 60, in 3 public education institutions, all of them in Bucharest. The corresponding group pairs were composed of: 15 boys in $5^{\text {th }}$ grade, 15 girls in $5^{\text {th }}$ grade, 15 boys in $8^{\text {th }}$ grade and 15 girls in $8^{\text {th }}$ grade. Therefore, 8 groups were formed as follows: 4 groups of students with disabilities and 4 groups of students in mainstream schools. Each group corresponded to the other in gender and the grade in which students were enrolled. The subjects were selected using the "statistical step method".

\section{Assessment methods}

The anthropometric measurements considered the height and body mass of the student (Cordun, 1999, p. 75). With the resulting data, the Body Mass Index was calculated using the formula:

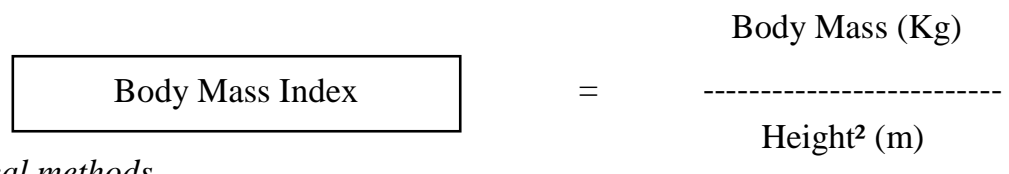

\section{Statistical methods}

Creating the research design required the use of nonparametric methods, which intervened as data processing techniques. In our case, we used the U-test technique to compare the data scored by the student groups. The statistical method was predicted by Mann-Whitney.

The $\mathrm{U}$ test is one of the most powerful nonparametric methods. It uses the level of each result in the general classification and serves as a way of testing the null hypothesis (H0), according to which two independent samples are randomly chosen from the representative populations (Labăr, 2008, p. 128).

For the collected data, the statistical mathematical program used was SPSS 24 for Windows (Popa, 2008, pp. 196-201). This program ranked the average result for each variable of the students in the four groups, the value of the Mann-Whitney U Test for two independent samples and the significance entry level. In our case, the significance level was $\mathrm{p}<0.05$.

\section{Results}

A. After analysing and comparing the data obtained from the tests performed by the subjects in the two groups (group 1 - special education, subjects with severe mental deficiencies corresponding in age with students in $5^{\text {th }}$ grade from mainstream schools, boys; group 2 - mainstream schools, $5^{\text {th }}$ grade, boys), the following results were obtained:

- Height: the average scores obtained by the subjects in the two groups were 11.90 for students with severe mental deficiencies and 19.10 for students enrolled in mainstream schools. After applying the MannWhitney Test, the obtained U-value was 58.500. The difference between the two groups proved to be statistically significant $(\mathrm{p}=0.023)$. (Figure 1 )

- Weight: the average scores obtained by the subjects in the two groups were 11.73 for students with severe mental deficiencies and 19.27 for students enrolled in mainstream schools. After applying the MannWhitney Test, the obtained U-value was 56.000 . The difference between the two groups proved to be statistically significant. (Figure 1) 


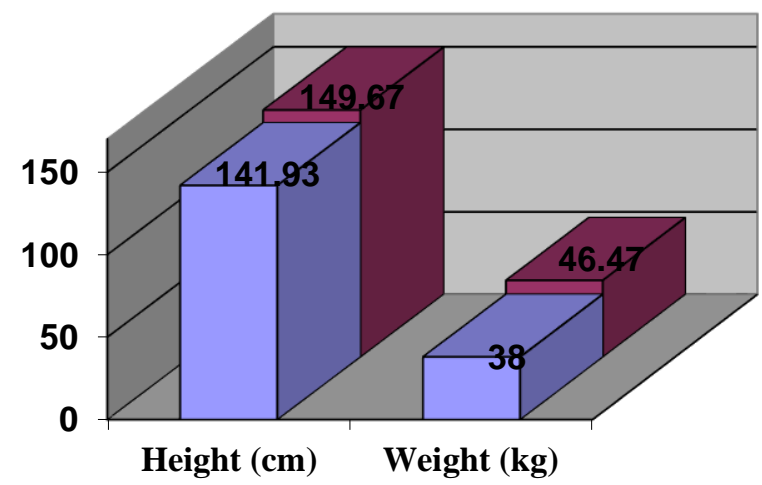

The average value scored by boys in special schools

Figure 1. Comparison between the height and weight values of boys in $5^{\text {th }}$ grade enrolled in public schools and their correspondents with mental deficiencies

- Body Mass Index: the average scores obtained by the subjects in the two groups were 14.40 for students with severe mental deficiencies and 16.60 for students enrolled in mainstream schools. After applying the Mann-Whitney Test, the obtained U-value was 96.000. The difference between the two groups is not statistically significant $(\mathrm{p}=0.512)$. (Table 1$)$

Table 1. The average BMI scored by boys enrolled in $5^{\text {th }}$ grade in mainstream schools and boys enrolled in $5^{\text {th }}$ grade in the special educational system

\begin{tabular}{lc}
\hline & Average BMI value \\
\hline Special Education System & 18.93 \\
Mainstream Schools & 20.46 \\
\hline
\end{tabular}

B. After analysing and comparing the data obtained from the tests performed by the subjects in the two groups (group 3 - special education, subjects with severe mental deficiencies corresponding in age with students in $8^{\text {th }}$ grade from mainstream schools, boys; group 4 - mainstream schools, $8^{\text {th }}$ grade, boys), the following results were obtained:

- Height: the average scores obtained by the subjects in the two groups were 11.47 for students with severe mental deficiencies and 19.53 for students enrolled in mainstream schools. After applying the MannWhitney Test, the obtained U-value was 52.000. The difference between the two groups proved to be statistically significant $(\mathrm{p}=0.012)$. (Figure 2 )

- Weight: the average scores obtained by the subjects in the two groups were 14.33 for students with severe mental deficiencies and 16.67 for students enrolled in mainstream schools. After applying the MannWhitney Test, the obtained U-value was 95.000. The difference between the two groups is not statistically significant $(\mathrm{p}=0.467)$. (Figure 2)

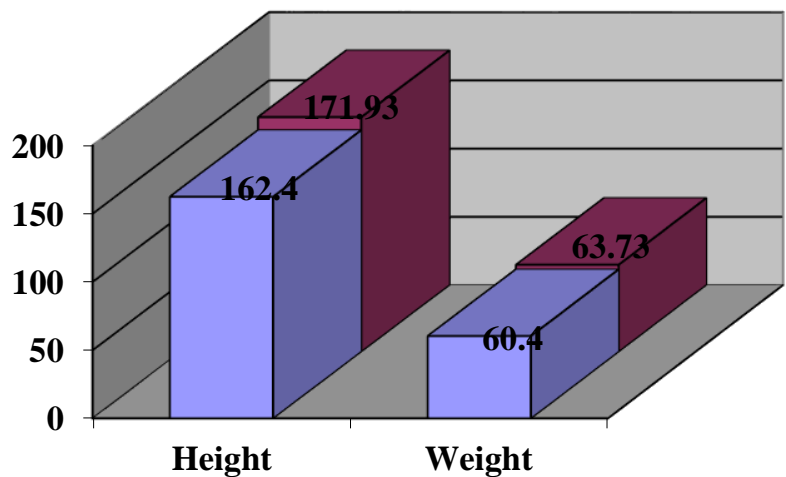

The average value scored by boys in special schools

The average value scored by boys in mainstream schools

Figure 2. Comparison between the height and weight values of boys in $8^{\text {th }}$ grade enrolled in public schools and their correspondents with mental deficiencies 
- Body Mass Index: the average scores obtained by the subjects in the two groups were 16.73 for students with severe mental deficiencies and 14.27 for students enrolled in mainstream schools. After applying the Mann-Whitney Test, the obtained U-value was 94.000. The difference between the two groups is not statistically significant $(\mathrm{p}=0.443)$. (Table 2 )

Table 2. The average BMI scored by boys enrolled in $8^{\text {th }}$ grade in mainstream schools and boys enrolled in $8^{\text {th }}$ grade in the special educational system

\begin{tabular}{lc}
\hline & Average BMI value \\
\hline Special Education System & 22.75 \\
Mainstream Schools & 21.5 \\
\hline
\end{tabular}

C. After analysing and comparing the data obtained from the tests performed by the subjects in the two groups (group 5 - special education, subjects with severe mental deficiencies corresponding in age with students in $5^{\text {th }}$ grade from mainstream schools, girls; group 6 - mainstream schools, $5^{\text {th }}$ grade, girls), the following results were obtained:

- Height: the average scores obtained by the subjects in the two groups were 11.33 for students with severe mental deficiencies and 19.67 for students enrolled in mainstream schools. After applying the MannWhitney Test, the obtained U-value was 50.000. The difference between the two groups proved to be statistically significant $(\mathrm{p}=0.009)$. (Figure 3 )

- Weight: the average scores obtained by the subjects in the two groups were 15.00 for students with severe mental deficiencies and 16.00 for students enrolled in mainstream schools. After applying the MannWhitney Test, the obtained U-value was 105.000. The difference between the two groups is not statistically significant $(\mathrm{p}=0.755)$. (Figure 3 )

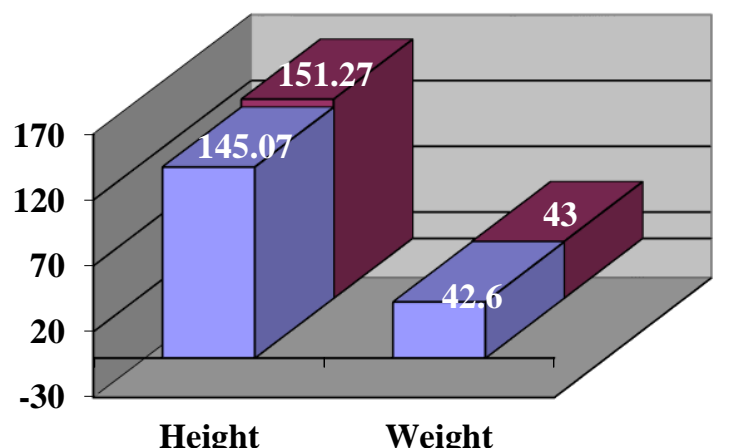

The average value scored by girls in special schools

The average value scored by girls in mainstream schools

Figure 3. Comparison between the height and weight values of girls in $5^{\text {th }}$ grade enrolled in mainstream schools and their correspondents with mental deficiencies

- Body Mass Index: the average scores obtained by the subjects in the two groups were 17.57 for students with severe mental deficiencies and 13.43 for students enrolled in mainstream schools. After applying the Mann-Whitney Test, the obtained U-value was 81.500 . The difference between the two groups is not statistically significant $(\mathrm{p}=0.198)$. (Table 3$)$

Table 3. The average BMI scored by girls enrolled in $5^{\text {th }}$ grade in mainstream schools and girls enrolled in $5^{\text {th }}$ grade in the special educational system

\begin{tabular}{lc}
\hline & Average BMI value \\
\hline Special Education System & 20.53 \\
Mainstream Schools & 18.7 \\
\hline
\end{tabular}

D. After analysing and comparing the data obtained from the tests performed by the subjects in the two groups (group 7 - special education, subjects with severe mental deficiencies corresponding in age with students in $8^{\text {th }}$ 
grade from mainstream schools, girls; group 8 - mainstream schools, $8^{\text {th }}$ grade, girls), the following results were obtained:

- Height: the average scores obtained by the subjects in the two groups were 9.73 for students with severe mental deficiencies and 21.27 for students enrolled in mainstream schools. After applying the MannWhitney Test, the obtained U-value was 26.000. The difference between the two groups proved to be statistically significant $(\mathrm{p}=0.001)$. (Figure 4$)$

- Weight: the average scores obtained by the subjects in the two groups were 11.57 for students with severe mental deficiencies and 19.43 for students enrolled in mainstream schools. After applying the MannWhitney Test, the obtained U-value was 53.500. The difference between the two groups proved to be statistically significant $(\mathrm{p}=0.014)$. (Figure 4$)$

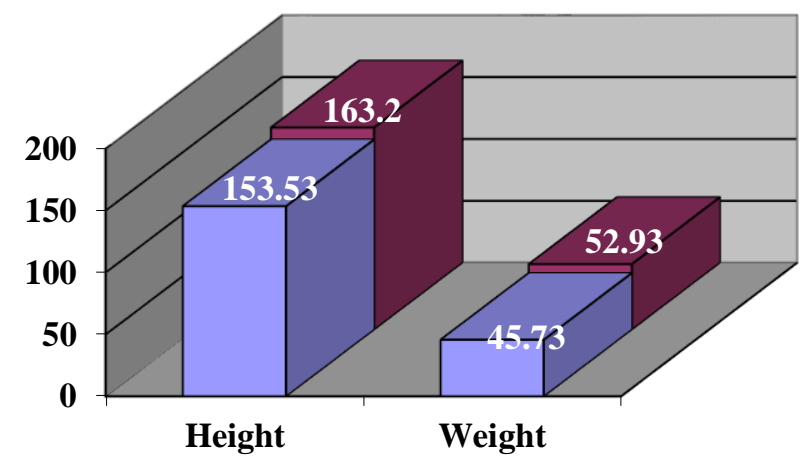

The average value scored by girls in special schools

The average value scored by girls in mainstream schools

Figure 4. Comparison between the height and weight values of girls in $8^{\text {th }}$ grade enrolled in mainstream schools and their correspondents with mental deficiencies

- Body Mass Index: the average scores obtained by the subjects in the two groups were 14.90 for students with severe mental deficiencies and 16.10 for students enrolled in mainstream schools. After applying the Mann-Whitney Test, the obtained U-value was 103.500. The difference between the two groups is not statistically significant $(\mathrm{p}=0.709)$. (Table 4$)$

Table 4. The average BMI scored by girls enrolled in $8^{\text {th }}$ grade in mainstream schools and girls enrolled in $8^{\text {th }}$ grade in the special educational system

\begin{tabular}{lc}
\hline & Average BMI value \\
\hline Special Education System & 20.53 \\
Mainstream Schools & 18.7 \\
\hline
\end{tabular}

\section{Discussion and Conclusion}

Following the analysis and comparison of the data obtained in the tests conducted with the mentally disabled subjects enrolled in special education and the students enrolled in mainstream middle schools, we can draw some conclusions:

- the statistical mathematical calculation showed significant differences in height between the compared groups: girls and boys in $5^{\text {th }}$ and $8^{\text {th }}$ grades;

- in terms of weight, significant differences between the two categories of subjects (boys in $5^{\text {th }}$ grade and girls in $8^{\text {th }}$ grade) were recorded. There were no significant differences between the $5^{\text {th }}$ grade girls and $8^{\text {th }}$ grade boys;

- although, in terms of weight, there were significant differences between almost all groups, in the case of body mass index, no differences were recorded for any of the compared groups.

In order to certify the obtained conclusions, we propose a comparison of the Body Mass Index by means of percentile growth graphs (Kuczmarski et al., 2002, pp. 31-32) (Figure 5). 
International Proceedings of Human Motricity/ ICPESK 2019

Supplementary Issue of Discobolul - Physical Education, Sport and Kinetotherapy Journal, 2019

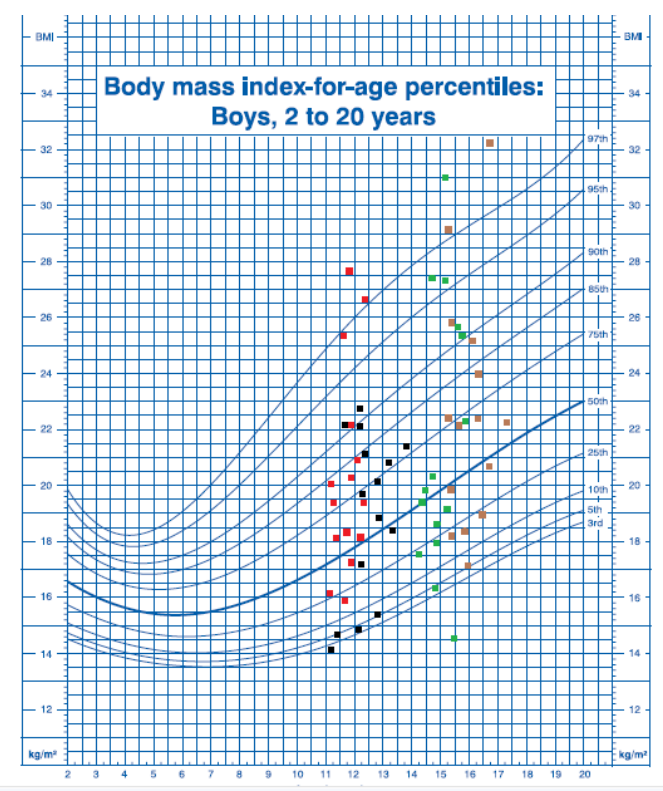

Boys, $5^{\text {th }}$ grade, mainstream schools

Boys, $5^{\text {th }}$ grade, special schools

Boys, $8^{\text {th }}$ grade, mainstream schools

Boys, $8^{\text {th }}$ grade, special schools

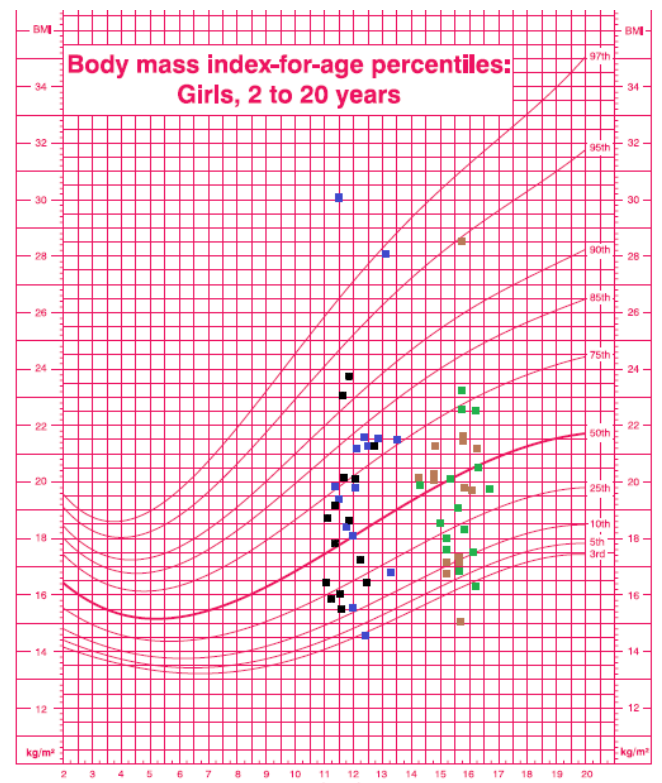

Girls, $5^{\text {th }}$ grade, special schools

Girls, $5^{\text {th }}$ grade, mainstream schools

Girls, $8^{\text {th }}$ grade, special schools

Girls, $8^{\text {th }}$ grade, mainstream schools

Figure 5. Distribution of Body Mass Index values by BMI percentiles

Table 5. The distribution of students according to the BMI value

\begin{tabular}{|c|c|c|c|c|c|c|c|c|}
\hline BMI Percentile & $\begin{array}{c}\text { Boys, } \\
5^{\text {th }} \\
\text { grade, } \\
\text { SS }\end{array}$ & $\begin{array}{c}\text { Boys, } \\
5^{\text {th }} \\
\text { grade, } \\
\text { MS }\end{array}$ & $\begin{array}{c}\text { Boys, } \\
8^{\text {th }} \\
\text { grade, } \\
\text { SS }\end{array}$ & $\begin{array}{c}\text { Boys, } \\
8^{\text {th }} \\
\text { grade, } \\
\text { MS }\end{array}$ & $\begin{array}{c}\text { Girls, } \\
5^{\text {th }} \\
\text { grade, } \\
\text { SS }\end{array}$ & $\begin{array}{c}\text { Girls, } \\
5^{\text {th }} \\
\text { grade, } \\
\text { MS }\end{array}$ & 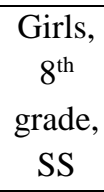 & $\begin{array}{c}\text { Girls, } \\
8^{\text {th }} \\
\text { grade, } \\
\text { MS }\end{array}$ \\
\hline BMI $\geq 95^{\text {th }}$ percentile & 0 & 3 & 2 & 3 & 2 & 0 & 0 & 1 \\
\hline $85^{\text {th }} \leq \mathrm{BMI}<95^{\text {th }}$ percentile & 4 & 0 & 3 & 2 & 2 & 2 & 0 & 0 \\
\hline $5^{\text {th }} \leq \mathrm{BMI}<85^{\text {th }}$ percentile & 10 & 12 & 10 & 9 & 10 & 13 & 14 & 13 \\
\hline $\mathrm{BMI}<5^{\text {th }}$ percentile & 1 & 0 & 0 & 1 & 1 & 0 & 1 & 1 \\
\hline
\end{tabular}

It can be noticed (Table 5) that the distribution of students according to the Body Mass Index is close for all 8 groups, the values of most students being between the $5^{\text {th }}$ percentile and the $85^{\text {th }}$ percentile, which frames them into the category of children with no problems, from the point of view of their state of nutrition.

At the end of the research, we compare the average values of the students with disabilities with the values presented by Stănescu et al. (2015) for the $5^{\text {th }}$ grade students, in terms of Body Mass Index (Table 6).

Table 6. Average Body Mass Index values

\begin{tabular}{lccc}
\hline & Values for special schools & $\begin{array}{c}\text { Values for mainstream } \\
\text { schools in Bucharest }\end{array}$ & $\begin{array}{c}\text { Values for national } \\
\text { mainstream schools }\end{array}$ \\
\hline Boys & 18.93 & 19.53 & 18.50 \\
Girls & 20.53 & 19.41 & 18.32 \\
\hline
\end{tabular}


We conclude by saying that the ratio of body mass to waist has close values for students with intellectual disabilities and students enrolled in mainstream schools.

In this regard, we propose that the annual design of the learning units for Physical education and sport, which target the harmonious physical development of students with intellectual disabilities, should be achieved by respecting the same rules as for schoolchildren in mainstream education.

\section{References}

Cordun, M. (1999). Kinetologie medicală [Medical kinesiology]. București: Axa.

Frey, G. C., \& Chow, B. (2006). Relationship between BMI, physical fitness and motor skills in youth with mild intellectual disabilities. International Journal of Obesity, 30(5), 861-867. https://doi.org/10.1038/sj.ijo.0803196

Hartman, E., Houwen, S., Scherder, E., \& Visscher, C. (2010). On the relationship between motor performance and executive functioning in children with intellectual disabilities. Journal of Intellectual Disability Research, 54(5), 468-477. https://doi.org/10.1111/j.1365-2788.2010.01284.x

Kuczmarski, R. J., Ogden, C. L., Guo, S. S., Grummer-Strawn, L. M., Flegal, K, M., Mei, Z., ... Johnson, C. L. (2002). 2000 CDC growth charts for the United States: Methods and development. Vital Health Statistics, $11(246)$

Retrieved

from https://www.researchgate.net/publication/303286548_2000_CDC_Growth_Charts_for_the_United_States_met hods_and_development

Labăr, A. V. (2008). SPSS pentru ştiinţele educației [SPSS for education sciences]. Iaşi: Polirom.

Lloyd, M., Temple, V. A., \& Foley, J. T. (2012). International BMI comparison of children and youth with intellectual disabilities participating in Special Olympics. Research in Developmental Disabilities, 33(6), 17081714. https://doi.org/10.1016/j.ridd.2012.04.014

Popa, M. (2008). Statistică pentru psihologie. Teorie şi aplicaţii SPSS [Statistics for psychology. SPSS theory and applications]. Iaşi: Polirom.

Stănescu, M., Cojocaru, V., Tudor, V., Ciolcă, C., Mujea, A. M., \& Stoicescu, M. (2015). Raport privind evaluarea potențialului somatic, funcțional și motric al populației școlare din România [Report on the assessment of the somatic, functional and motor potential of the Romanian school population]. București: Discobolul.

Stewart, L., Van de Ven, L., Katsarou, V., Rentziou, E., Doran, M., Jackson, P., ... Wilson, D. (2010). High prevalence of obesity in ambulatory children and adolescents with intellectual disability. Journal of Intellectual Disability Research, 53(10), 882-886. https://doi.org/10.1111/j.1365-2788.2009.01200.x 